\author{
*For correspondence: \\ blewitt@wehi.edu.au (MEB); \\ gouil.q@wehi.edu.au (QG) \\ ${ }^{\dagger}$ These authors contributed equally \\ to this work
}

\section{Maternal SMCHD1 controls both imprinted Xist expression and imprinted $X$ chromosome inactivation}

\author{
Iromi Wanigasuriya $\mathbb{( D}^{1,2}$, Sarah A Kinkel ${ }^{1,2}$, Tamara Beck $\mathbb{( D}^{1,2}$, Ellise A Roper (iD ${ }^{3}$, \\ Kelsey Breslin (iD) ${ }^{1,2}$, Heather J Lee $\mathbb{D}^{3}$, Andrew Keniry $\mathbb{D}^{1,2^{*}}$, Matthew E Ritchie $\mathbb{D}^{1,2,4}$, \\ Marnie E Blewitt $\mathbb{1}^{1,2^{* \dagger}}$, Quentin Gouil $\mathbb{D}^{1,2^{* \dagger}}$
}

\begin{abstract}
${ }^{1}$ Walter and Eliza Hall Institute of Medical Research, Parkville, Australia; ${ }^{2}$ The Department of Medical Biology, The University of Melbourne, Parkville, Australia; ${ }^{3}$ The School of Biomedical Sciences and Pharmacy, The University of Newcastle, Newcastle, Australia; ${ }^{4}$ The Department of Mathematics and Statistics, The University of Melbourne, Parkville, Australia
\end{abstract}

\begin{abstract}
Embryonic development is dependent on the maternal supply of proteins through the oocyte, including factors setting up the adequate epigenetic patterning of the zygotic genome. We previously reported that one such factor is the epigenetic repressor SMCHD1, whose maternal supply controls autosomal imprinted expression in mouse preimplantation embryos and mid-gestation placenta. In mouse preimplantation embryos, $\mathrm{X}$ chromosome inactivation is also an imprinted process. Combining genomics and imaging, we show that maternal SMCHD1 is required not only for the imprinted expression of Xist in preimplantation embryos, but also for the efficient silencing of the inactive $X$ in both the preimplantation embryo and mid-gestation placenta. These results expand the role of SMCHD1 in enforcing the silencing of Polycomb targets. The inability of zygotic SMCHD1 to fully restore imprinted X inactivation further points to maternal SMCHD1's role in setting up the appropriate chromatin environment during preimplantation development, a critical window of epigenetic remodelling.
\end{abstract}

\section{Introduction}

$X$ chromosome inactivation $(\mathrm{XCl})$ in female mammals is a paradigm of epigenetic regulation, where hundreds of genes on a single chromosome coordinately undergo silencing (Lyon, 1961, 1962). In the common ancestor of therian mammals, $\mathrm{XCl}$ evolved as a mechanism of sex chromosome dosage compensation, balancing female $X$-linked expression at levels similar to males possessing only one X chromosome (Lyon, 1963; Reik and Lewis, 2005). The ancestral form of XCl is likely imprinted, with preferential silencing of the paternal $X$, whereas random $X$ inactivation is derived (Reik and Lewis, 2005; Deakin et al., 2009). In marsupials, imprinted X inactivation is maintained in all tissues (Cooper et alo, 1971) whereas in rodents or cattle it only persists in extraembryonic tissues that gives rise to the placenta, while the embryo-proper reactivates the paternal X before random inactivation of either the maternal or paternal chromosome takes place (Okamoto et al., 2011). In humans, only random $X$ inactivation occurs.

In mice, imprinted $X$ inactivation originates in the preimplantation embryo (Okamoto and Heard, 
2006). Systematic silencing of the paternal $X$ is caused by a Polycomb-mediated repressive imprint laid down during oogenesis, which prevents the long non-coding RNA Xist from being expressed (Tada et al., 2000; Chiba et al., 2008; Inoue et al., 2017). Paternal expression of Xist thus leads to silencing of the paternal X (Heard et alo, 2004). Maternal effect genes that control the epigenetic patterning of the oocyte and early zygote are important for the correct imprinted expression of Xist Inoue et al. (2017); Harris et al. (2019); Mei et al. (2021); Chen et al. (2021). The genomic region surrounding Xist houses multiple positive and negative regulators of Xist expression, and is termed the X-inactivation centre (Galupa and Heard, 2018).

We previously established that the maternal supply of Structural Maintenance of Chromosome Hinge Domain containing 1 (SMCHD1) regulates some of the Polycomb-dependent imprinted genes on autosomes (Wanigasuriya et al., 2020). Both Xist and autosomal Polycomb-dependent imprinted genes are non-canonical imprinted genes, as they rely on Polycomb marks for their imprinted expression rather than DNA methylation as canonical imprinted genes do. Based on this role of maternal SMCHD1 and the known involvement of zygotic SMCHD1 in XCI (Blewitt et al., 2008; Gendrel et al., 2012), we investigated whether maternal SMCHD1 also played a role in regulating the imprinted expression of Xist, and whether it affected silencing of the inactive X. Through epigenomic and imaging analyses of preimplantation embryos and mid-gestation placentae, we show that SMCHD1 is also a maternal effect gene with regard to imprinted $X$ chromosome inactivation.

\section{Results}

\section{Maternal deletion of Smchd1 results in aberrant Xist expression from the maternal allele}

To determine the role of maternal SMCHD1 on imprinted Xist expression and X inactivation, we ablated Smchd1 in mouse oocytes using the MMTV-Cre transgene and crossed the dams with wild-type sires from a different strain to allow allele-specific analyses (Figure 1a, as reported in Wanigasuriya et al. (2020)). We analysed single-embryo methylome and transcriptome data for Smchd $1^{\text {mat } \Delta}$ and control Smchd $1^{\text {wt }}$ E2.75 embryos (16-32 cells), when zygotic SMCHD1 only just starts to accumulate (Wanigasuriya et al., 2020).

We previously reported very little genome-wide differential expression in male preimplantation embryos without maternal SMCHD1 (Wanigasuriya et al., 2020). Consistent with that, there was also very little genome-wide differential expression in female $S m c h d 1^{\text {mat } \Delta}$ embryos compared to wild-type controls (Figure $1 b$ and c). However, the maternal copy of Xist was a striking outlier. Maternal Xist is normally silenced in the early embryo due to a Polycomb-mediated imprint (Inoue et al., 2017; Harris et al., 2019; Mei et al., 2021; Chen et al., 2021). Here maternal Xist was activated both in the female and male Smchd $1^{\text {mat } \Delta}$ embryos (Figure $1 \mathrm{~b}$ and c). Although striking, maternal Xist loss of imprinting was not completely penetrant: 4 out of 8 male and 3 out of 4 female Smchd $1^{\text {mat } \Delta}$ embryos showed increased levels of maternal Xist expression (Figure 1d). In the female embryos, paternal Xist expression still outweighed expression from the maternal allele. This could be due to low levels of zygotic SMCHD1 beginning to accumulate around E2.75 (Wanigasuriya et al., 2020) and partial silencing of maternal Xist, or additional repression mechanisms independent of SMCHD1. The partial penetrance could similarly be due to zygotic SMCHD1 expression, or it may reflect true biological variation in the response to maternal SMCHD1 ablation.

At the blastocyst stage the X-inactivation centre is partially methylated (Prissette, 2001; McGraw et al., 2013), so we asked whether the failure to silence maternal Xist could be due to a failure to acquire DNA methylation at the X-inactivation centre, using our E2.75 embryo DNA methylation data. However, the whole X-inactivation centre including the maternal Xist promoter and Xite/DXPas34 remained unmethylated in male and female wild-type E2.75 embryos, and there was no difference in the Smchd $1^{\text {mat } \Delta}$ embryos that displayed loss of imprinting (Figure 1 supplement 1 ). The loss of Xist silencing was therefore not linked to a defect in DNA methylation. 
bioRxiv preprint doi: https://doi.org/10.1101/2021.10.21.465360; this version posted October 21, 2021. The copyright holder for this preprint (which was not certified by peer review) is the author/funder, who has granted bioRxiv a license to display the preprint in perpetuity. It is made available under aCC-BY-NC-ND 4.0 International license.

a.

$$
\text { Smchd } 1^{\text {dell/t }} \text { MMTV-Cre }{ }^{T /+}
$$
Smchd t/I/I $^{\text {MMTV-Cre }}{ }^{+/+}$

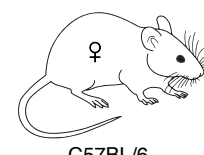

C57BL/6

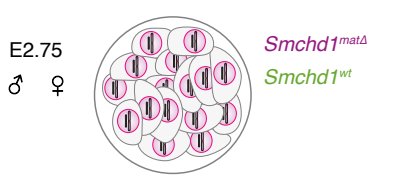

c.

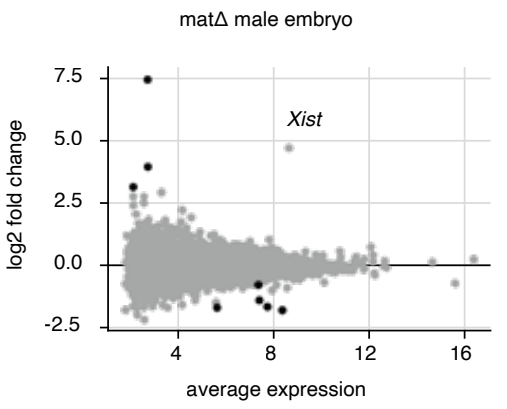

Smchd1 $1^{+/+}$ b.
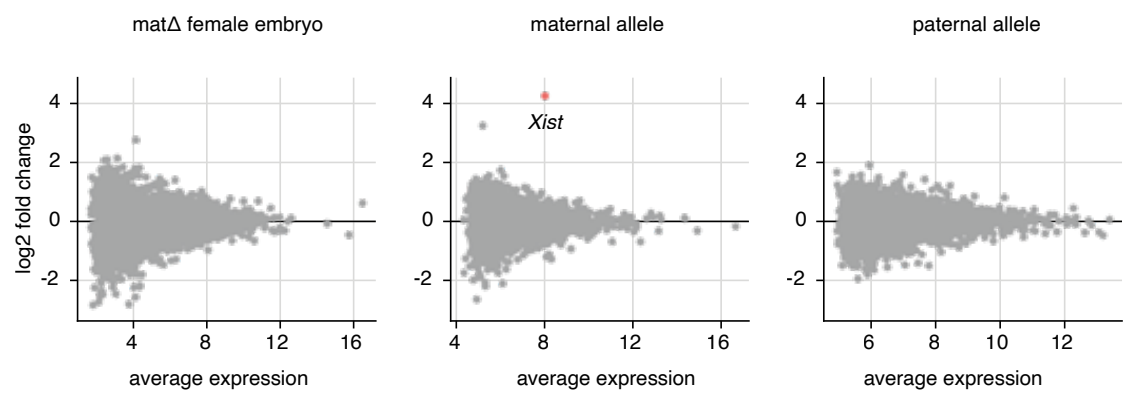

d.
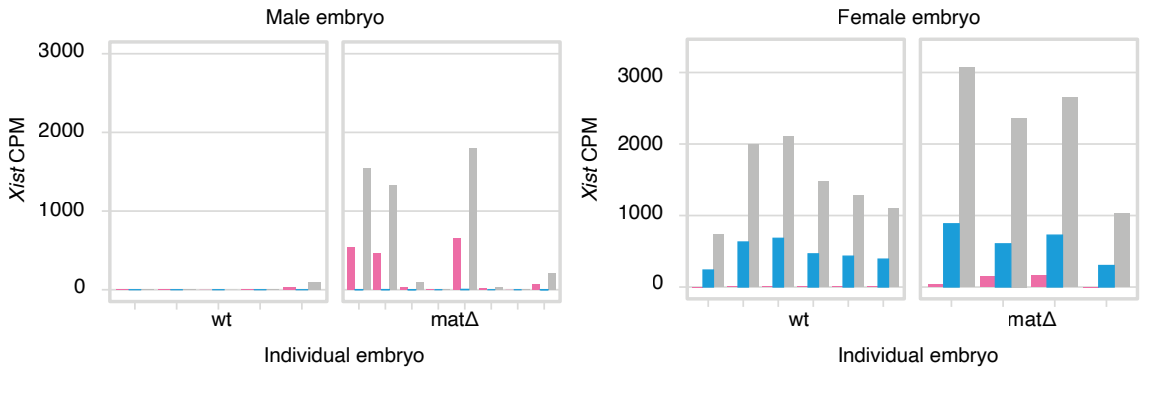

Maternal (b6) allele

Paternal (cast) allele

Figure 1. Maternal deletion of Smchd1 results in aberrant Xist expression from the maternal allele in both male and female E2.75 preimplantation embryos. (a) Schematic of genetic crosses for maternal deletion of Smchd1. (b) Genome-wide differential expression in Smchd1 ${ }^{m a t} \Delta$ female embryos vs wt, before haplotyping and after separating maternal and paternal alleles. Average expression is in log2 counts per million (cpm). Only maternal Xist is significantly differentially expressed (adjusted p-value $=6 \mathrm{e}-4)$. (c) Genome-wide differential expression in Smchd $1^{\text {mat } \Delta}$ male embryos vs wt, without haplotyping. Significant genes are coloured black (5\% FDR). Xist is not

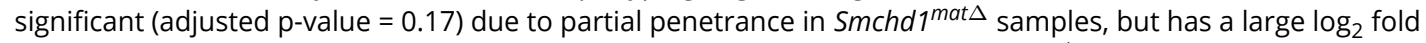
change (4.74). (d) Xist expression in individual male and female wt and Smchd $1^{\text {mat } \Delta}$ E2.75 embryos. CPM:

counts per million (of total library size before haplotyping). "Mixed" counts refer to counts without haplotyping. Females: $\mathrm{n}=6 \mathrm{wt}$ and 4 mat $\Delta$; males: $\mathrm{n}=5 \mathrm{wt}$ and 8 mat $\Delta$.

Figure 1-Figure supplement 1. DNA methylation at the $\mathrm{X}$ inactivation center in female and male E2.75 wt embryos and $\mathrm{Smchd} 1^{\text {mat } \Delta}$ embryos. Histogram tracks show methylation in single embryos at individual CpG sites (0-100\%, 4 wild-type and 4 mat $\Delta$ embryos shown for each sex). Note that coverage in single-embryo whole-genome bisulfite sequencing is sparse, only $0-2 X$. The aggregate line plots show the average methylation per genotype across $10 \mathrm{~kb}$ windows (sliding by $5 \mathrm{~kb}, 0-100 \%$ ). Females: $\mathrm{n}=6$ wt and 4 mat $\Delta$; males: $\mathrm{n}=5 \mathrm{wt}$ and 8 mat $\Delta$. 


\section{Imprinted X chromosome inactivation is altered in Smchd1 ${ }^{\text {mat } \Delta}$ morulae}

We then asked whether maternal Xist expression was functionally linked to the silencing of the maternal $X$ chromosome. Although at the genome-wide level few individual genes passed the significance threshold for differential expression (Figure $1 \mathrm{~b}$ and $\mathrm{c}$ ), the distribution of $\log _{2}$ fold changes (mat $\Delta$ vs wt) shifted significantly for X-linked genes (Figure 2a). In $S m c h d 1^{\text {mat } \Delta}$ males, the genes from the maternal $X$ chromosome tended to be downregulated (mean $\log _{2}$ fold change $=$ -0.16 , equivalent to a reduction by $11 \%, p$-value $=2.4 e-5)$, consistent with $X i s t$-mediated silencing. In $S m c h d 1^{m a t} \Delta$ females, the alleles on the maternal $X$ were not significantly downregulated (mean $\log _{2}$ fold change $=-0.094$, $p$-value $=0.18$ ), while the paternal alleles were upregulated (mean $\log _{2}$ fold change $=0.20$, equivalent to an increase by $15 \%$, $p$-value $=7.6 e-6$ ). When subsetting the embryos that specifically showed Xist loss of imprinting, the effects were stronger for the males ( $X$ downregulation by $25 \%$ on average) and unchanged for the females (Figure 2 supplement 1 ). At E2.75, imprinted $X$ inactivation is normally ongoing and does not yet affect all the genes on the paternal $X$ chromosome (Patrat et al., 2009; Borensztein et al., 2017). Accordingly in our data, the paternal $X$ in the wild-type females was downregulated by $45 \%$ on average (Figure $2 \mathrm{~b}$ ). This is stronger than the upregulation of the paternal X in Smchd $1^{\text {mat } \Delta}$ females, meaning that the paternal X in Smchd $1^{\text {mat } \Delta}$ females retained some degree of silencing. Taken together with the partial silencing of the maternal X in Smchd $1^{\text {mat } \Delta}$ males, this demonstrated that the absence of maternal SMCHD1 did not preclude an initiation of $X$ silencing following Xist expression. However, the fact that the silencing is incomplete compared to the wild-type scenario may indicate either that maternal SMCHD1 contributes to these early stages of imprinted $X$ inactivation, or that the aberrant Xist expression (biallelic in females, from the maternal $\mathrm{X}$ in males) does not allow $\mathrm{XCl}$ to proceed at its normal rate.

To further investigate the stage and mechanisms of XCI in the E2.75 embryos, we analysed CpG island methylation on each allele of the $X$ chromosome. In wild-type female embryos, average CGI methylation on the paternal inactive $X$ remained low and similar to that of the maternal $X$ and the male X (Figure 2c). CpG island methylation in $S m c h d 1^{\text {mat } \Delta}$ embryos was indistinguishable from the wild types. These results imply that maternal SMCHD1 has no role in the methylation of the inactive $X$ at this time.

Genome-wide, there was little evidence of differential methylation between wild-type and Smchd1 ${ }^{\text {mat } \Delta}$ female E2.75 embryos (Figure 2 supplement 2), similar to what we reported in male embryos (Wanigasuriya et al., 2020). Methylation at CpG islands was very low, similar to the CGIs of $X$ chromosomes (Figure 2c), and there were no significant differentially methylated CGIs (Figure 2 supplement 2). Across gene promoters, methylation levels were more broadly distributed but highly consistent between wild-type and $S m c h d 1^{\text {mat } \Delta}$ embryos. There was a relative excess of hypermethylated promoters in the $S m c h d 1^{\text {mat } \Delta}$ samples, but with mild (<30\%) differences and making up only $0.5 \%$ of all promoters ( 246 hypermethylated, 10 hypomethylated, out of $52 \mathrm{k}$ promoters) with no overlap with differentially methylated promoters in males. Over $10 \mathrm{~kb}$ windows sliding across the whole genome, 445 were hypermethylated including 42 also hypermethylated in the males, and 14 were hypomethylated (no overlap with the males), out of 544,659 bins. Together, these results confirmed that maternal SMCHD1 as little to no impact on genome-wide DNA methylation at the morula stage.

\section{Absence of maternal SMCHD1 causes biallelic expression of Xist in the same cells, but silencing is restored by zygotic SMCHD1}

As our transcriptomic data had single-embryo (16-cell) but not single-cell resolution, we could not discriminate between the possibility that maternal and paternal Xist were co-expressed in the very same cells of female Smchd $1^{\text {mat }}$ embryos, or rather that each parental allele of Xist was monoallelically expressed in individual cells. To overcome this limitation, we performed allelespecific RNA-FISH in E2.75 embryos (Figure 3a). The female wild-type embryos showed only paternal Xist expression in all cells, as expected for imprinted XCl at the 16-cell stage (Figure $3 \mathrm{~b}$ and d). By contrast in the Smchd $1^{\text {mat } \Delta}$ female embryos, Xist was expressed biallelically with maternal Xist 
a.

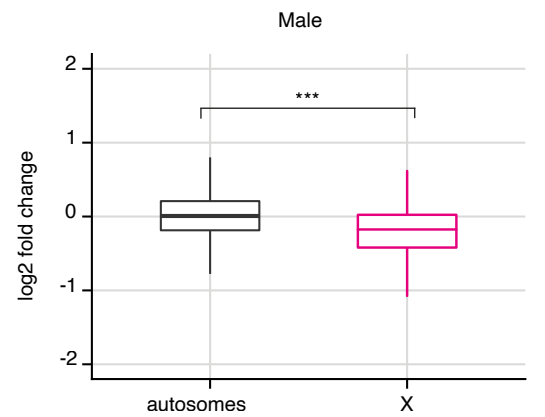

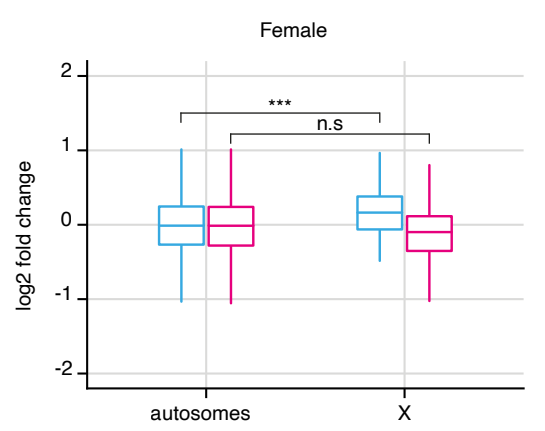

b.

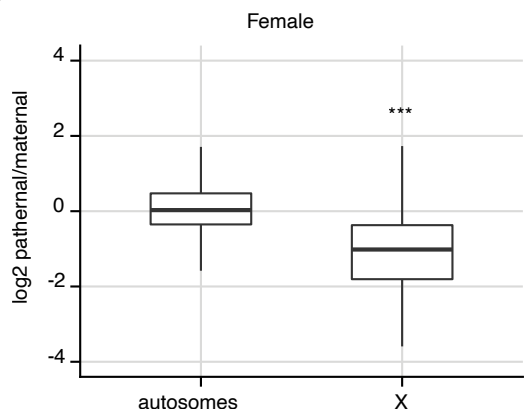

c.
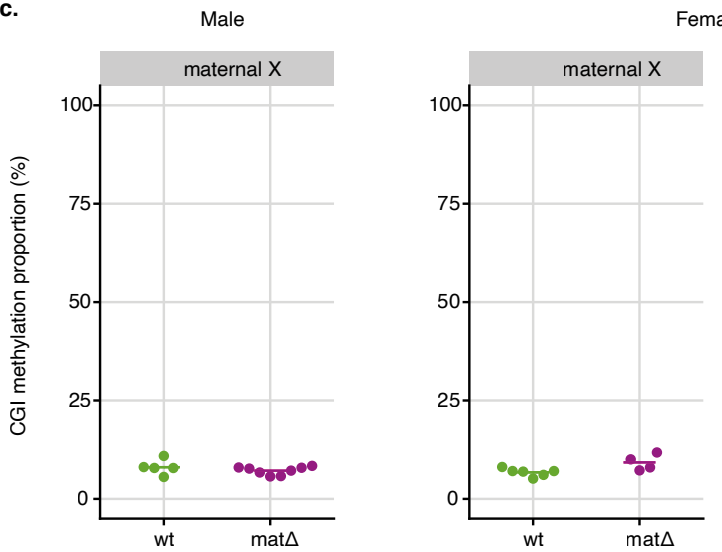

Female

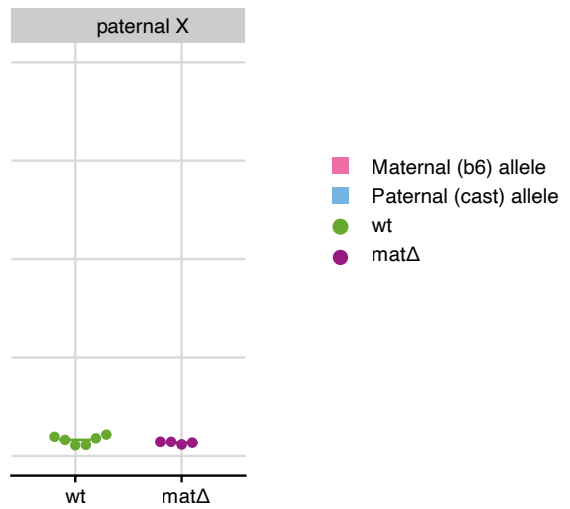

Figure 2. Maternal deletion of Smchd1 results in aberrant $\mathrm{XCl}$ in male and perturbed imprinted $\mathrm{XCl}$ in female E2.75 preimplantation embryos. (a) Distribution of $S m c h d 1^{m a t} \Delta$ vs wt gene expression $\log _{2}$ fold changes on autosomes and the $\mathrm{X}$ chromosome for male and female E2.75 embryos. For females, results of the allele-specific differential expression analysis are shown, with paternal alleles in blue and maternal alleles in pink. Two-sample t-tests; male: $p=2.4 e-5$; female paternal allele $p=7.6 e-6$; female maternal allele $p=0.18$. (b) Distribution of paternal over maternal log2 expression ratios in wt female E2.75 embryos. Paternal X-linked genes are significantly repressed ( $p=1.5 e-4$, one-sample t-test). (c) Average CpG island (CGI) methylation on the $\mathrm{X}$ chromosomes of individual Smchd $1^{\text {wt }}$ and $S m c h d 1^{\text {mat } \Delta}$ male and female E2.75 embryos. Females: $\mathrm{n}=6 \mathrm{wt}$ and 4 mat $\Delta$; males: $\mathrm{n}=5 \mathrm{wt}$ and 8 mat $\Delta$.

Figure 2-Figure supplement 1. Distribution of $S m c h d 1^{\text {mat } \Delta}$ vs wt gene expression $\log _{2}$ fold changes on autosomes and the $X$ chromosome for male and female E2.75 embryos, retaining only mat $\Delta$ embryos with loss of Xist imprinting.

Figure 2-Figure supplement 2. Whole-genome differential methylation analysis between female Smchd1 ${ }^{\text {mat } \Delta}$ and wild-type E2.75 embryos. For CpG islands (CGIs, 13k regions), promoters ( $-4 \mathrm{~kb}$ to $+1 \mathrm{~kb}$ regions, $52 \mathrm{k}$ regions) and 10-kb windows (sliding by $5 \mathrm{~kb}$, $500 \mathrm{k}$ regions), the average methylation level in wild types is plotted against the average methylation in Smchd $1^{\text {mat }} \Delta$ embryos. Significant Differentially Methylated Regions (DMRs, FDR < 5\% and absolute difference in methylation > 20\%) are coloured in red (hypermethylation) or blue (hypomethylation). Females: $\mathrm{n}=6$ wt and 4 mat $\Delta$. 
detectable in a subset of cells (from 2 out of 16 , up to 13 out 16 cells, Figure $3 b$ and d). In males, we observed maternal Xist only in Smchd $1^{\text {mat } \Delta}$ embryos (Figure $2 \mathrm{c}$ and e), also in a subset of cells, which was consistent with the transcriptomic data. Therefore the detection of both paternal and maternal Xist in the female $S m c h d 1^{\text {mat } \Delta}$ transcriptomes was not due to an alternating pattern of mono-allelic expression, as seen in random X-chromosome inactivation after chromosome choice, but indeed due to the loss of imprinting of Xist. Penetrance was again only partial, as we did not observe biallelic expression in every cell of every embryo, and the proportion of cells with biallelic expression was variable between embryos.

We reasoned that the onset of zygotic SMCHD1 expression may restore silencing of maternal Xist. To test this, we performed allele-specific RNA-FISH on E3.5 embryos (early blastocysts, 32-64 cells). In the outer trophectoderm layer that gives rise to the placenta, Xist expression in Smchd $1^{\text {mat } \Delta}$ embryos was restored to the wild-type pattern: only paternal Xist expression in female embryos and no Xist expression in male embryos (Figure $3 \mathrm{f}-\mathrm{i}$ ). This suggests that the underlying imprint was successfully set up in oocyte development and maintained through the first 4-5 cell divisions in the absence of maternal SMCHD1, allowing zygotic SMCHD1 to rescue the loss of imprinted Xist expression. This places SMCHD1 downstream of the Polycomb-dependent imprint, similar to what we proposed for other non-canonically imprinted genes (Wanigasuriya et al., 2020).

\section{Maternal deletion of Smchd1 does not affect Xist expression in E14.5 placentae but compromises XCI}

Previously we showed loss of maternal SMCHD1 resulted in defects in the imprinted expression of some autosomal imprinted genes in the mid-gestation (E14.5) placenta, despite the presence of zygotic SMCHD1 for 11 days (Wanigasuriya et al., 2020). Although the correct pattern of imprinted Xist expression was restored by E3.5, we investigated whether any residual effects of maternal SMCHD1 ablation on imprinted X inactivation could be observed in E14.5 placentae.

We performed allele-specific bulk RNA-seq on the embryonic portion of female E14.5 placentae for mat $\Delta$, wild-type and heterozygous (paternally transmitted mutation) embryos. Comparing with heterozygous samples allowed to account for potential haploinsufficiency for Smchd1 after zygotic SMCHD1 activation. Allelic Xist expression in Smchd ${ }^{\text {mat }}$ samples was indistinguishable from that of wild-type samples, consistent with the restored imprinted Xist expression by E3.5 (Figure 4a). Expression from the active $X$ chromosome was also largely normal in heterozygous and $S m c h d 1^{\text {mat } \Delta}$ samples (Figure $4 \mathrm{~b}$, left panels). From the paternal inactive X however, 36 out of 179 informative genes were upregulated (informative: expressed and containing a SNP; 5\% FDR) in heterozygous samples (Figure $4 \mathrm{~b}$, top right panel), while 107 out of 213 informative genes (5\% FDR) were upregulated in the $S m c h d 1^{\text {mat } \Delta}$ samples (Figure $4 \mathrm{~b}$, bottom right panel). There were 34 $X$-linked genes that were upregulated in both genotypes (Figure $4 c)$. These common genes tended to have larger $\log _{2}$ fold changes in the maternal null samples $(p<0.001$, paired t-test, Figure $4 d)$. This showed that while Smchd 1 haploinsufficiency impacted imprinted X inactivation in the E14.5 placentae, the loss of maternal SMCHD1 had a more severe effect, both in terms of the number of genes that escape silencing and the extent to which they escape.

To investigate whether the failure to properly silence the inactive $X$ could be linked to SMCHD1's role in the methylation of CpG islands, we performed Reduced Representation Bisulfite Sequencing (RRBS) in Smchd1 ${ }^{\text {mat }}$ and wt female E14.5 placentae. CpG island methylation was reduced in Smchd $1^{\text {mat } \Delta}$ placentae, from $25 \%$ median methylation to $15 \%$ (Figure $4 \mathrm{e}$ ). The low level of methylation observed in the placental tissue is as expected as this tissue has less methylation than embryonic tissues (Schroeder et al., 2015). The failure to silence Xi genes was thus correlated with a failure to adequately methylate the Xi CpG islands.

These data show that the perturbations induced by the lack of SMCHD1 preimplantation persist for at least 11 days post zygotic Smchd1 activation, despite normal Xist expression at E3.5 and E14.5. 
bioRxiv preprint doi: https://doi.org/10.1101/2021.10.21.465360; this version posted October 21, 2021. The copyright holder for this preprint (which was not certified by peer review) is the author/funder, who has granted bioRxiv a license to display the preprint in perpetuity. It is made available under aCC-BY-NC-ND 4.0 International license.

a.
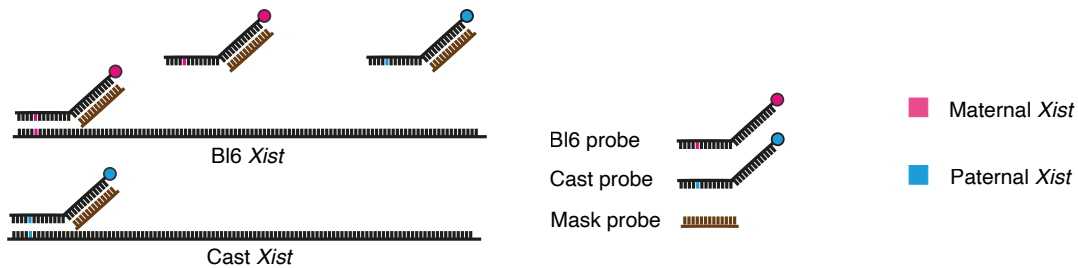

E2.75 embryo

b.

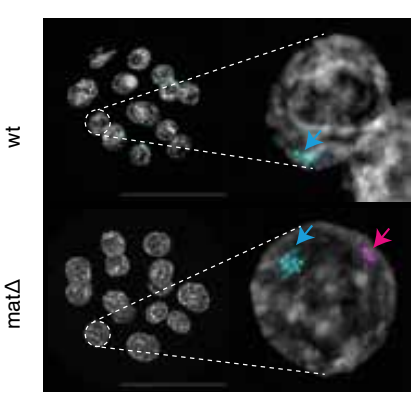

d.

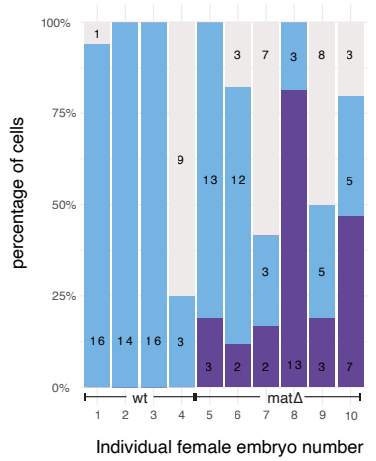

c. Male embryo

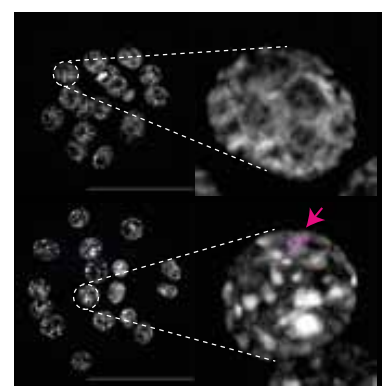

e.

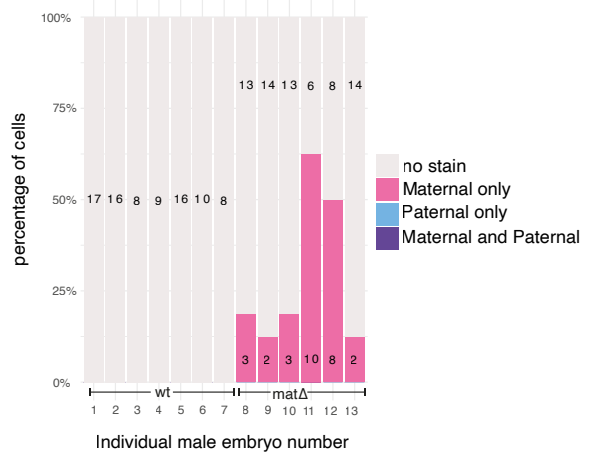

f. Female embryo

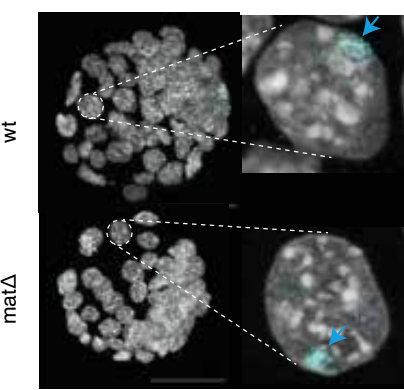

h.

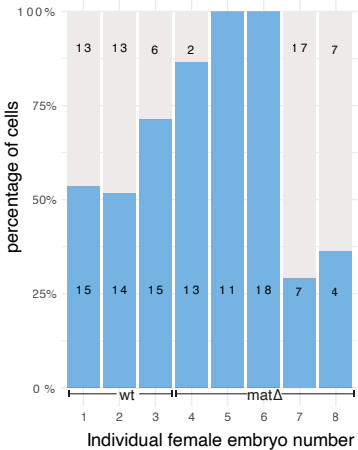

g.

Male embryo

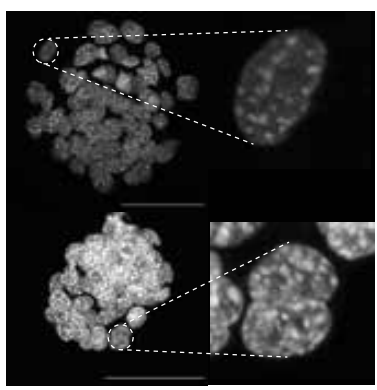

i.

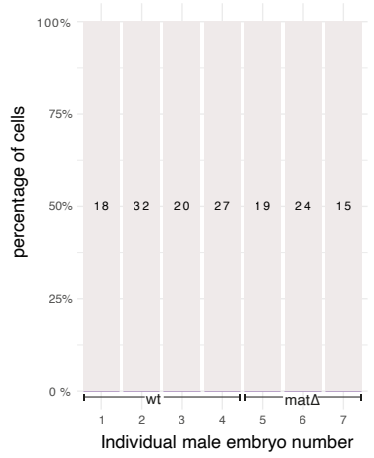

Figure 3. Maternal deletion of Smchd1 results in transient biallelic Xist exist expression in morula. (a) Schematic representation of the allele-specific Xist RNA FISH. (b,c) Imaging of female (b) and (c) male wt and Smchd $1^{\text {mat } \Delta}$ E2.75 embryos. Maternal (BL6) and paternal (Cast) alleles are indicated by coloured arrows. (d,e) Percentage and number of cells in E2.75 female (d) and male (e) embryos with maternal, paternal or biallelic Xist expression. $(\mathrm{f}, \mathrm{g})$ Imaging of female ( $\mathrm{f}$ ) and (g) male wt and Smchd1 ${ }^{\text {mat } \Delta}$ E3.5 embryos. (h,i) Percentage and number of cells in E3.5 female (h) and male (i) embryos with maternal, paternal or biallelic Xist expression. Scale bar: $50 \mu \mathrm{m}$. Numbers of embryos and cells scored are indicated on the figure. 
bioRxiv preprint doi: https://doi.org/10.1101/2021.10.21.465360; this version posted October 21, 2021. The copyright holder for this preprint (which was not certified by peer review) is the author/funder, who has granted bioRxiv a license to display the preprint in perpetuity. It is made available under aCC-BY-NC-ND 4.0 International license.

a.

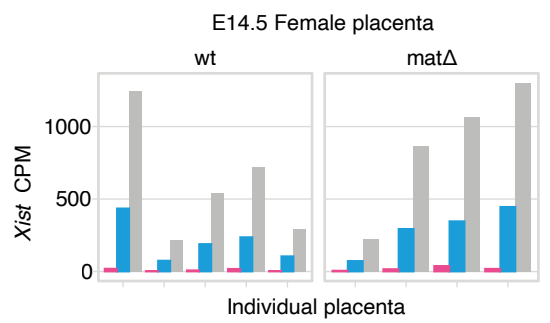

Maternal Paternal mixed

c.

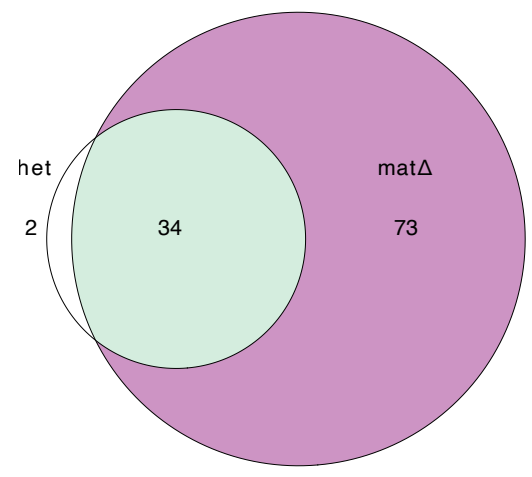

d.

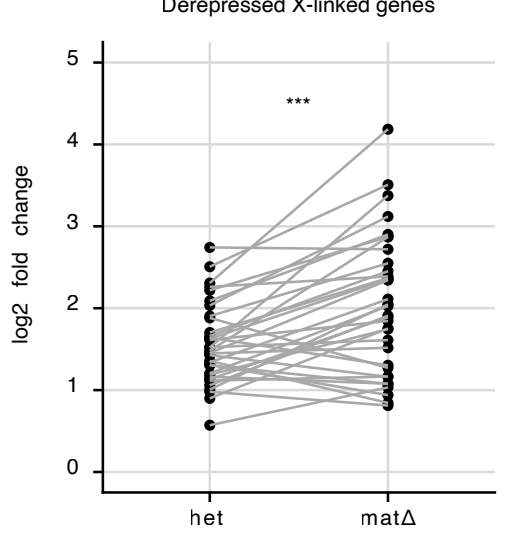

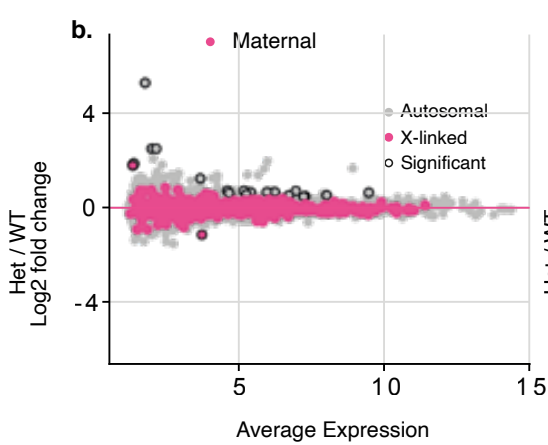
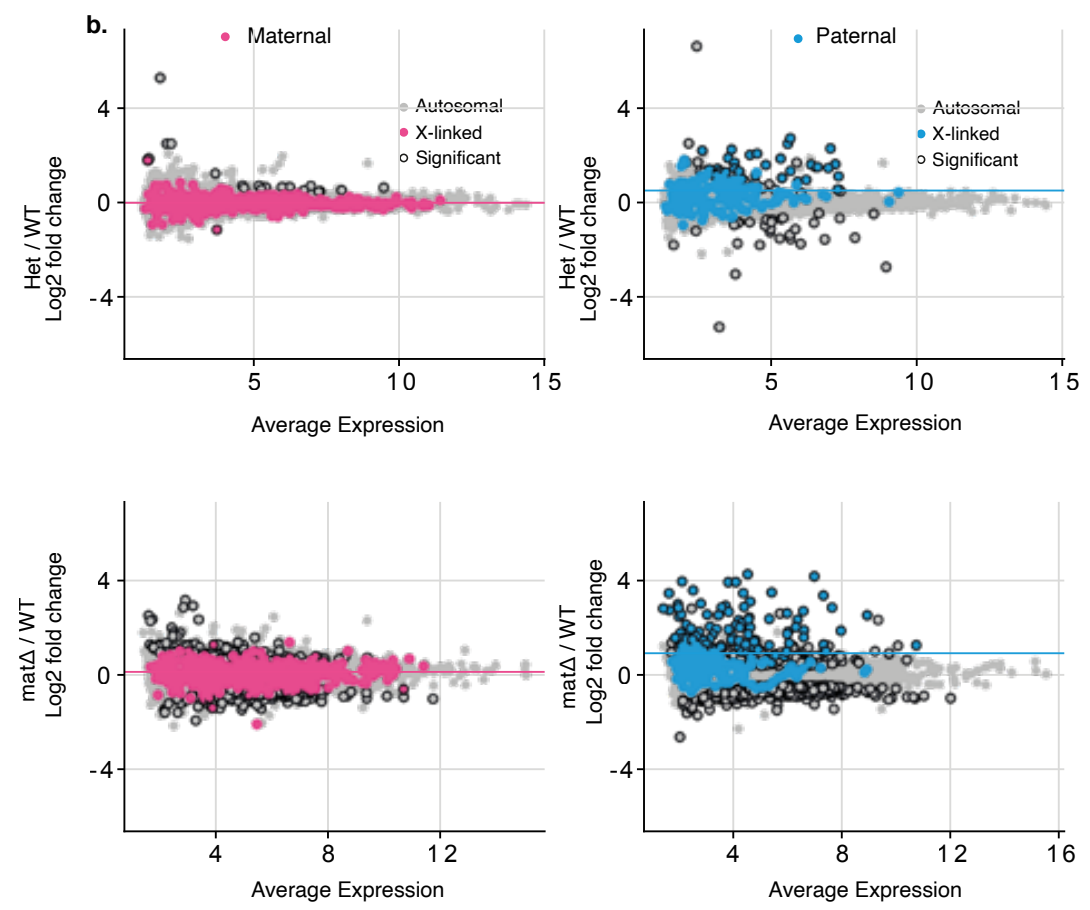

e.

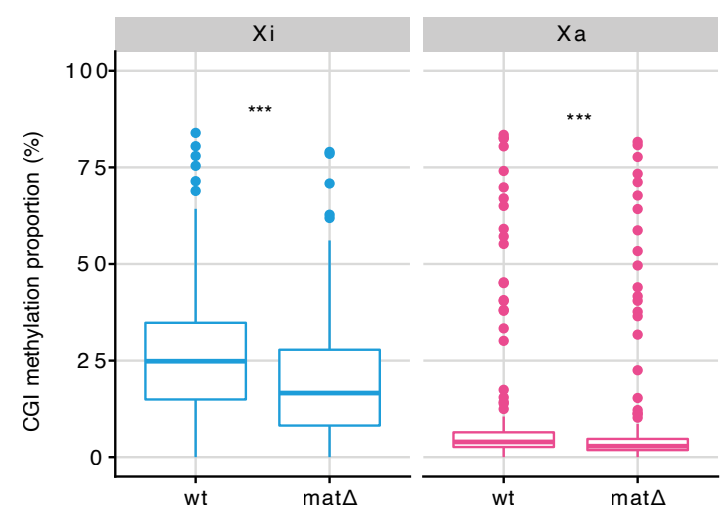

Figure 4. Maternal deletion of Smchd1 results in failed silencing of the Xi in E14.5 placentae despite normal Xist expression. (a) Xist expression separated by maternal allele, paternal allele or total counts (without haplotyping) in female Smchd1 ${ }^{\text {mat } \Delta}$ or wt E14.5 placentae. The reads are shown as a proportion of the total library size (counts per million, CPM) before haplotyping. (b) Differential gene expression between Smchd $1^{\text {het }}$ and Smchd $1^{\text {wt }}$ E14.5 placentae, and Smchd $1^{\text {mat } \Delta}$ and Smchd $1^{\text {Wt }}$ in E14.5 placentae split by alleles. X-linked genes are coloured, differentially expressed genes that pass the genome-wide 5\% FDR are circled. Average expression in log2 cpm. The paternal $X$ is the inactive $X$ is mouse placenta. (c) Overlap between genes that are significantly differentially expressed in Smchd1 $1^{\text {het }}$ and in Smchd $1^{\text {mat }} \Delta$ placentae. (d) Comparison of the $\log _{2}$ fold changes of the differentially expressed genes common to the $S m c h d 1^{\text {het }}$ and $S m c h d 1^{\text {mat }} \Delta$ placentae. $p=8 \mathrm{e}-5$, paired t-test. (e) Distribution of CpG island methylation on the Xi and Xa in Smchd $1^{\text {mat } \Delta}$ and Smchd $1^{\text {wt }}$ E14.5 female placentae. Xi: $\mathrm{p}<1 \mathrm{e}-6 ;$ Xa: $\mathrm{p}=2 \mathrm{e}-5$; paired t-tests. $\mathrm{n}=4$ MMTV-Cre Smchd1 ${ }^{\text {mat }} \Delta$ and $\mathrm{n}=5 \mathrm{wt} ; \mathrm{n}=6$ het and littermate $\mathrm{n}=4 \mathrm{wt}$ control E14.5 placentae. 


\section{Discussion}

Previously we identified that SMCHD1 modulates the imprinted expression of a set of autosomal genes that we predicted was secondary to deposition of H3K27me3 by PRC2 (Wanigasuriya et al., 2020). This happened at two classes of loci: genes where the PRC2 mark is the primary imprint (noncanonical imprinted genes), and imprinted clusters where the primary DNA methylation imprint leads to secondary H3K27me3 deposition. Here we extend these findings, demonstrating that maternal SMCHD1 also enforces imprinted expression of the long non-coding RNA Xist during preimplantation embryo development. Xist belongs to the class of non-canonical imprinted genes, its promoter being labelled with H2K119ub and H3K27me3 during oocyte development (Inoue et al., 2017; Mei et al., 2021; Chen et al., 2021). In the absence of maternal SMCHD1, we observed biallelic Xist expression in female E2.75 embryos, and maternal Xist expression in male embryos.

Previous work by Harris et al. (2019) and Inoue et al. (2017) showed that loss of Xist imprinting leads to failed imprinted XCl. A maternal deletion of Polycomb gene Eed led to the erasure of the imprint on maternal Xist and complete loss of Xist imprinted expression. Harris et al. observed subsequent male lethality and a conversion from imprinted to random $\mathrm{XCl}$ in the female placentae. However, upon maternal Smchd1 deletion we observed neither sex-specific embryonic lethality (Wanigasuriya et al., 2020) nor random XCI in the female placentae. By contrast, Xist loss of imprinting was incompletely penetrant (in a subset of embryos and cells) at E2.75 and normal maternal Xist silencing was fully restored by E3.5. We interpret the rescue of maternal Xist silencing, coinciding with zygotic SMCHD1 synthesis, as an indication that the underlying Polycomb imprint on Xist remained intact. This once again places SMCHD1 downstream of the Polycomb machinery. Recent work has shown that PRC1-deposited H2AK119ub is also involved in imprinted Xist expression and imprinted XCI Mei et al. (2021); Chen et al. (2021). Since a PRC1-dependent model of SMCHD1 recruitment has been reported for the inactive X (Jansz et al., 2018b; Wang et al., 2019), this model likely extends to Xist and other non-canonical imprinted genes. Thus a single H2AK119ub-dependent recruitment mechanism could apply to both maternal and zygotic SMCHD1, at autosomes as well as at the $X$ chromosome.

Although Xist loss of imprinting was only transient, the absence of SMCHD1 for the first three days of embryonic development had lasting effects on $\mathrm{X}$ inactivation. The initial phases of $\mathrm{X}$ inactivation, driven by the Xist long non-coding RNA, did not strictly require SMCHD1 to silence genes: Xist expression from the maternal allele was able to initiate gene silencing on the $X$ chromosome in male E2.75 embryos lacking SMCHD1, and paternal $X$ silencing was not abolished in E2.75 Smchd $1^{\text {mat } \Delta}$ female embryos. However, silencing efficiency was reduced in these females, which might be attributable to several factors. Biallelic Xist expression may delay the commitment to silencing or dilute silencing between the two X chromosomes. Alternatively, maternal SMCHD1 could contribute to some of the early paternal $X$ silencing in addition to its role in imprinted maternal Xist repression. More surprisingly, X inactivation defects were observable in E14.5 female placentae, despite more than 10 days of zygotic SMCHD1 presence. Half of the detectable Xi-linked genes were not appropriately silenced, which could not simply be explained by Smchd1 haploinsufficiency. In addition, failed gene silencing was associated with a failure to methylate $\mathrm{CpG}$ islands on the Xi to the same level as the wild-type. This persisting disruption to epigenetic silencing bore similarities with two other maternal effects seen in embryos with maternal Smchd 1 deletions: the partial loss of autosomal imprinting in the mid-gestation placentae (Wanigasuriya et al., 2020) and the disrupted Hox gene regulation in tissue of the embryo-proper (Benetti et al., 2021).

From this cumulative evidence, it is clear that maternal SMCHD1 is required during preimplantation development to set up an epigenetic state that is required for correct gene regulation later on. What this particular epigenetic state is and how SMCHD1 creates it remains obscure, but it is tempting to speculate that, like for SMCHD1 recruitment, a single mechanism explains SMCHD1's mode of action for both maternal and zygotic SMCHD1, at all of its diverse targets. SMCHD1 is required for the repression of Hox genes, protocadherin clusters, imprinted genes, the inactive $\mathrm{X}$, 
and tandem repeat arrays (Jansz et al., 2018a; Benetti et al., 2021; Gendrel et al., 2012; Chen et al., 2015; Mould et al., 2013; Blewitt et al., 2008; Lemmers et al., 2012; Gdula et al., 2019). All these targets display abundant Polycomb marks. In the absence of SMCHD1, H3K27me3 spreads and H3K9me3 is lost on the Xi (Jansz et al., 2018b; Ichihara et al., 2021). SMCHD1's role at its targets may be to facilitate the positive feedback loops of Polycomb repression (Blackledge and Klose, 2021), concentrating the Polycomb machinery, Polycomb marks and repressors at specific loci to both reach a threshold required for efficient silencing as well as avoid ectopic redistribution of Polycomb. This mechanism would be conceptually close to what has been proposed for plant MORC proteins, GKHL ATPases like SMCHD1, which are proposed to anchor a chromatin silencing pathway to target loci (Xue et al., 2021). Ensuring focal enrichment of Polycomb repressive marks might in turn allow adjacent regions to adopt other chromatin states, explaining SMCHD1's proposed role as an insulator (Chen et al., 2015; Jansz et al., 2018a; Gdula et al., 2019). These well-defined linear chromatin blocks would influence the three-dimensional self-organisation of the chromatin into domains of cognate epigenetic states, perhaps explaining the effect of SMCHD1 on long-range chromatin interactions (Jansz et al., 2018a; Wang et al., 2018). The potential role of SMCHD1 in solidifying initial silencing by Polycomb may then allow some of its targets to transition to other modes of repression, in particular H3K9 methylation and DNA methylation. Preimplantation Polycomb imprints acquire secondary DNA methylation and H3K9me2 in the placenta Hanna et al. (2019); Chen et al. (2019); Zeng et al. (2021); Andergassen et al. (2021); Raas et al. (2021), similar to the $\mathrm{Xi} \mathrm{CpG}$ islands becoming methylated by DNMT3B and H3K9me3 accumulating on the Xi (Gendrel et al., 2012; Keniry et al., 2016; Ichihara et al., 2021). In the absence of SMCHD1, these transitions fail: DNA methylation at non-canonical imprinted gene Jade 1 does not accumulate Wanigasuriya et al. (2020), nor does Xi CpG island methylation (Gendrel et al., 2012)(this study).

SMCHD1 links together epigenetic processes that appear more and more closely related as our knowledge increases. Non-canonical imprinting, imprinted $\mathrm{X}$ inactivation, aspects of canonical imprinting and random $X$ inactivation all borrow from the same Polycomb/SMCHD1/H3K9me/DNA methylation toolbox. Each process offers a window into a general but complex interplay of epigenetic mechanisms. Further elucidation of SMCHD1's molecular mechanisms will shed light on all these fundamental processes.

\section{Materials and Methods}

\section{Mouse genetics}

All mice were bred and maintained in house at The Walter and Eliza Hall Institute of Medical Research (WEHI) using procedures approved by in-house ethics approval committee (approval numbers 2014.026, 2018.004, 2020.048 and 2020.050).

Smchd $1^{\text {mat } \Delta}$ embryos were produced from a cross between Smchd1 $1^{-f f}$ MMTV-Cre ${ }^{T /+}$ dams and CAST/EiJ sires. Smchd $1^{\text {het }}$ embryos were produced from the reciprocal cross. Control Smchd $1^{\text {wt }}$ embryos were produced from crosses between Smchd flffl $^{f / 2 M T V-C r e e^{+/+}}$dams and CAST/Eij sires, and as littermates of the Smchd $1^{\text {het }}$ embryos.

The MMTV-Cre Smchd1-1fl line was generated by backcrossing MMTV-Cre transgene line A (Wagner et al., 1997) onto the C57BL/6 background from the FVB/N background for more than 10 generations. These mice contain a combination of Smchd1 deleted allele (Smchd1) in trans to the Smchd1 floxed (Smchd $1^{\mathrm{fl}}$ ) allele (de Greef et al., 2018). The CAST/EiJ strain used to achieve polymorphism necessary for allele-specific analyses was purchased from the Jackson laboratories.

\section{Single-embryo methylome and transcriptome sequencing}

Embryo collection, library preparation and data preprocessing were as described in Wanigasuriya et al. (2020). Male and female embryos were analysed in the same way.

RNA-seq reads from the E2.75 embryos were trimmed for adapter and low quality sequences using TrimGalore! v0.4.4, before mapping onto the GRCm38 mouse genome reference N-masked 
for Cast SNPs prepared with SNPsplit v0.3.2 (Krueger and Andrews, 2016) with HISAT2 v2.0.5 (Kim et al., 2015), in paired-end mode and disabling soft-clipping. Gene counts were obtained in R 3.5.1 ( $R$ Core Team, 2019) from bam files with the featureCounts function from the Rsubread package v1.32.1 (Liao et al., 2014, 2019), provided with the GRCm38.90 GTF annotation downloaded from Ensembl, and ignoring multi-mapping or multi-overlapping reads. Lowly expressed genes were filtered out with the filterByExpr function with option min.prop $=0.33$ in edgeR v3.24.0 (Robinson et al., 2010; McCarthy et al., 2012). Gene counts were normalised with the TMM method (Robinson and Oshlack, 2010). Differential gene expression between the Smchd ${ }^{\text {mat }}{ }^{4}$ and Smchd $1^{\text {wt }}$ embryos was performed using the glmFit and glmLRT functions. P-values were corrected with the Benjamini-Hochberg method (Benjamini and Hochberg, 1995). Differential expression results were visualized with Glimma 2.2.0 (Su et al., 2017; Kariyawasam et al., 2021).

Whole-genome bisulfite analysis of single E2.75 embryos was performed as in (Wanigasuriya et al., 2020).

\section{Bulk RNA-seq}

RNA-seq libraries from the embryonic portion of E14.5 mouse placentae were made as described in Wanigasuriya et al. (2020). Differential expression analysis was performed using the same strategy as for the above single-embryo RNA-seq.

\section{RRBS}

Library preparation and analysis was identical to Wanigasuriya et al. (2020).

\section{Allele-specific RNA-FISH on preimplantation embryos}

\section{Probe preparation}

Allele-specific Xist RNA FISH probes were generated as described (Levesque et al., 2013). Briefly, a set of short oligonucleotide probes ( 5 probes for each Xist allele) were designed to uniquely detect either the Bl6 or the Cast alleles of Xist exon 7. Each probe contained single nucleotide polymorphism (SNP) located at the fifth base pair position from the $5^{\prime}$ end that differs between the Bl6 and Cast. The 3' end of each oligonucleotide probe was fluorescently tagged using Quasar dyes (Biosearch technologies). Bl6-specific oligos were labelled with Quasar 570 and Cast-specific oligos labelled with Quasar 670. In addition to labeled SNP-overlapping oligonucleotides, a panel of 5 'mask' oligonucleotides were also synthesized (IDT). Exon 7 of Xist RNA was selected as the strand-specificXist guide probe. Exon 7 specific primers were designed (IDT) with T3 and T7 promoter overhangs. Exon 7 was amplified from $50 \mathrm{ng}$ of an Xist cDNA clone (Wutz and Jaenisch, 2000). Briefly, the PCR reaction contained cDNA, 5x Phusion HF reaction buffer (Cat \# 13058S), $1 \mu \mathrm{L}$ Phusion Taq, $10 \mathrm{mM}$ dNTP, and $10 \mu \mathrm{M}$ per forward and reverse primers. PCR cycle conditions were $98^{\circ} \mathrm{C}$ for 2 minutesutes; 30 cycles of $98^{\circ} \mathrm{C}$ for 30 seconds, $58^{\circ} \mathrm{C}$ for 30 seconds and $72^{\circ} \mathrm{C}$ for 30 seconds; $72^{\circ} \mathrm{C}$ for 4 minutes. PCR product was isolated using QIAquick gel extraction kit (Qiagen) according to manufacturer's instructions. Strand-specific Xist RNA probe was labelled with Fluorescein-12-UTP (Roche, Cat \# 11427857910) and ethanol precipitated as previously described (Hinten et alo, 2016). Probe was re-suspended in hybridisation buffer containing 10\% dextran sulfate, 2 X saline-sodium citrate (SSC) and $10 \%$ formamide.

\section{Allele-specific RNA FISH}

E2.75 embryos were collected and the zona pellucida removed by keeping in acid tyrode's solution (Sigma) for 2 minutes. Embryos were placed in the middle of Denhardt's treated cover slips in 1x PBS $6 \mathrm{mg} / \mathrm{ml}$ BSA using finely pulled Pasteur pipette. Excess 1x PBS $6 \mathrm{mg} / \mathrm{ml} \mathrm{BSA}$ was aspirated and embryos let dry for 20-30 minutes. Embryos were fixed and permeabilised with $50 \mu \mathrm{L}$ of $1 \%$ PFA in $1 \times$ PBS with $0.05 \%$ Tergitol for 5 minutes. Embryos were rinsed with three changes of $70 \%$ ethanol then dehydrated through an ethanol series $(85 \%, 95 \%, 100 \%) 2$ minutes each at room temperature. Samples were then air-dried for 5-10 minutes. 
Allele-specific Xist RNA FISH was performed on these embryos as previously described (Harris et al., 2019). The precipitated guide RNA probe was mixed with the BI6 and Cast detection probes, to a final concentration of $5 \mathrm{nM}$ per allele-specific oligo, and 10 nMmask probe, yielding a 1:1 mask:detection oligonucleotide ratio. Cover slips were hybridised to the combined probe overnight in a humid chamber at $37^{\circ} \mathrm{C}$. After overnight hybridisation, samples were washed twice in $2 x$ SSC with $10 \%$ formamide at $37^{\circ} \mathrm{C}$ for 30 minutes, followed by one wash in 2 XSS for five minutes at room temperature. A 1/250,000 dilution of DAPI (Invitrogen, Cat \# D21490) was added to the second 2X SSC with 10\% formamide wash. Cover slips were then mounted on slides in Vectashield (Vector Labs, Cat \# H-1000). Stained samples were imaged immediately using a LSM 880 (Zeiss) microscope.

\section{Acknowledgments}

We thank Andrea Morcom for assisting with preimplantation embryo flushing and Jessica Martin for mouse husbandry assistance. We also thank Sundeep Kalantry and Clair Harris for their assistance with allele specific FISH protocol.

\section{Funding}

This work was supported by a Bellberry-Viertel Senior Medical Researcher Fellowship to MEB and National Health and Medical Research Council grants to MEB and MER (GNT1098290), and MEB (GNT1194345). IW was supported by a Melbourne International Research Scholarship. Additional support was provided by the Victorian State Government Operational Infrastructure Support, Australian National Health and Medical Research Council IRIISS grant (9000653). HJL has received research funding from: The Cancer Institute NSW, Australia (ECF171145); The National Health and Medical Research Council, Australia (GNT1143614); The Ian Potter Foundation, Australia (20180029).

\section{Authors' contributions}

IW: Conceptualization, Investigation, Data curation, Formal analysis, Methodology, Writing - original draft, Writing - review and editing; SAK, TB, EAR, KB: Investigation; HJL, AK: Methodology, Resources, Supervision; MER: Methodology, Resources, Supervision, Writing - review and editing; MEB: Conceptualization, Methodology, Resources, Supervision, Writing - original draft, Writing - review and editing; QG: Conceptualization, Investigation, Data curation, Formal analysis, Methodology, Supervision, Writing - original draft, Writing - review and editing;

\section{Data availability}

Female single-embryo Methylome and Transcriptome sequencing, female E14.5 placenta RRBS and RNA-seq raw and processed data are available under GEO accession GSE186315. Male data from Wanigasuriya et al. (2020) are available under BioProject accession PRJNA530651.

\section{References}

Andergassen D, Smith ZD, Rinn JL, Meissner A. Diverse mechanisms for epigenetic imprinting in mammals. bioRxiv. 2021 Apr; http://biorxiv.org/lookup/doi/10.1101/2021.04.30.442087, doi: 10.1101/2021.04.30.442087.

Benetti N, Gouil Q, del Fierro AT, Beck T, Breslin K, Keniry A, McGlinn E, Blewitt ME. Maternal SMCHD1 regulates Hox gene expression and patterning in the mouse embryo. bioRxiv. 2021 Sep; http://biorxiv.org/lookup/doi/ 10.1101/2021.09.08.459528, doi: 10.1101/2021.09.08.459528.

Benjamini Y, Hochberg Y. Controlling the False Discovery Rate: A Practical and Powerful Approach to Multiple Testing. Journal of the Royal Statistical Society: Series B (Methodological). 1995 Jan; 57(1):289-300. https: //onlinelibrary.wiley.com/doi/10.1111/j.2517-6161.1995.tb02031.x, doi: 10.1111/j.2517-6161.1995.tb02031.x.

Blackledge NP, Klose RJ. The molecular principles of gene regulation by Polycomb repressive complexes. Nature Reviews Molecular Cell Biology. 2021 Aug; https:/ www.nature.com/articles/s41580-021-00398-y, doi: 10.1038/s41580-021-00398-y. 

available under aCC-BY-NC-ND 4.0 International license.

Blewitt ME, Gendrel AV, Pang Z, Sparrow DB, Whitelaw N, Craig JM, Apedaile A, Hilton DJ, Dunwoodie SL, Brockdorff N, Kay GF, Whitelaw E. SmcHD1, containing a structural-maintenance-of-chromosomes hinge domain, has a critical role in X inactivation. Nature Genetics. 2008 May; 40(5):663-669. http:/ / www. nature. com/articles/ng.142, doi: 10.1038/ng.142.

Borensztein M, Syx L, Ancelin K, Diabangouaya P, Picard C, Liu T, Liang JB, Vassilev I, Galupa R, Servant N, Barillot E, Surani A, Chen CJ, Heard E. Xist-dependent imprinted X inactivation and the early developmental consequences of its failure. Nature Structural \& Molecular Biology. 2017 Mar; 24(3):226-233. http://www. nature.com/articles/nsmb.3365, doi: 10.1038/nsmb.3365.

Chen K, Hu J, Moore DL, Liu R, Kessans SA, Breslin K, Lucet IS, Keniry A, Leong HS, Parish CL, Hilton DJ, Lemmers RJLF, van der Maarel SM, Czabotar PE, Dobson RCJ, Ritchie ME, Kay GF, Murphy JM, Blewitt ME. Genomewide binding and mechanistic analyses of Smchd1-mediated epigenetic regulation. Proceedings of the National Academy of Sciences. 2015 Jul; 112(27):E3535-E3544. http://www.pnas.org/lookup/doi/10.1073/pnas. 1504232112, doi: 10.1073/pnas.1504232112.

Chen Z, Djekidel MN, Zhang Y. Distinct dynamics and functions of H2AK119ub1 and H3K27me3 in mouse preimplantation embryos. Nature Genetics. 2021 Apr; http://www. nature.com/articles/s41588-021-00821-2, doi: 10.1038/s41588-021-00821-2.

Chen Z, Yin Q, Inoue A, Zhang C, Zhang Y. Allelic H3K27me3 to allelic DNA methylation switch maintains noncanonical imprinting in extraembryonic cells. Science Advances. 2019 Dec; 5(12):eaay7246. https:// advances.sciencemag.org/lookup/doi/10.1126/sciadv.aay7246, doi: 10.1126/sciadv.aay7246.

Chiba H, Hirasawa R, Kaneda M, Amakawa Y, Li E, Sado T, Sasaki H. De novo DNA methylation independent establishment of maternal imprint on X chromosome in mouse oocytes. genesis. 2008 Dec; 46(12):768-774. https://onlinelibrary.wiley.com/doi/10.1002/dvg.20438, doi: 10.1002/dvg.20438.

Cooper DW, Vandeberg JL, Sharman GB, Poole WE. Phosphoglycerate Kinase Polymorphism in Kangaroos provides Further Evidence for Paternal X Inactivation. Nature New Biology. 1971 Mar; 230(13):155-157. http://www. nature.com/articles/newbio230155a0, doi: 10.1038/newbio230155a0.

Deakin JE, Chaumeil J, Hore TA, Marshall Graves JA. Unravelling the evolutionary origins of X chromosome inactivation in mammals: insights from marsupials and monotremes. Chromosome Research. 2009 Jul; 17(5):671-685. http://link.springer.com/10.1007/s10577-009-9058-6, doi: 10.1007/s10577-009-9058-6.

Galupa R, Heard E. X-Chromosome Inactivation: A Crossroads Between Chromosome Architecture and Gene Regulation. Annual Review of Genetics. 2018 Nov; 52(1):535-566. https://www.annualreviews.org/doi/10.1146/ annurev-genet-120116-024611, doi: 10.1146/annurev-genet-120116-024611.

Gdula MR, Nesterova TB, Pintacuda G, Godwin J, Zhan Y, Ozadam H, McClellan M, Moralli D, Krueger F, Green CM, Reik W, Kriaucionis S, Heard E, Dekker J, Brockdorff N. The non-canonical SMC protein SmcHD1 antagonises TAD formation and compartmentalisation on the inactive $X$ chromosome. Nature Communications. 2019 Dec; 10(1):30. http://www.nature.com/articles/s41467-018-07907-2, doi: 10.1038/s41467-018-07907-2.

Gendrel AV, Apedaile A, Coker H, Termanis A, Zvetkova I, Godwin J, Tang YA, Huntley D, Montana G, Taylor S, Giannoulatou E, Heard E, Stancheva I, Brockdorff N. Smchd1-Dependent and -Independent Pathways Determine Developmental Dynamics of CpG Island Methylation on the Inactive X Chromosome. Developmental Cell. 2012 Aug; 23(2):265-279. https://linkinghub.elsevier.com/retrieve/pii/S1534580712002857, doi: 10.1016/j.devcel.2012.06.011.

de Greef JC, Krom YD, den Hamer B, Snider L, Hiramuki Y, van den Akker RFP, Breslin K, Pakusch M, Salvatori DCF, Slütter B, Tawil R, Blewitt ME, Tapscott SJ, van der Maarel SM. Smchd1 haploinsufficiency exacerbates the phenotype of a transgenic FSHD1 mouse model. Human Molecular Genetics. 2018 Feb; 27(4):716-731. https://academic.oup.com/hmg/article/27/4/716/4769583, doi: 10.1093/hmg/ddx437.

Hanna CW, Pérez-Palacios R, Gahurova L, Schubert M, Krueger F, Biggins L, Andrews S, Colomé-Tatché M, Bourc'his D, Dean W, Kelsey G. Endogenous retroviral insertions drive non-canonical imprinting in extraembryonic tissues. Genome Biology. 2019 Dec; 20(1):225. https://genomebiology.biomedcentral.com/articles/ 10.1186/s13059-019-1833-x, doi: 10.1186/s13059-019-1833-x.

Harris C, Cloutier M, Trotter M, Hinten M, Gayen S, Du Z, Xie W, Kalantry S. Conversion of random X-inactivation to imprinted X-inactivation by maternal PRC2. eLife. 2019 Apr; 8:e44258. https://elifesciences.org/articles/44258, doi: 10.7554/eLife.44258. 
Heard E, Chaumeil J, Masui O, Okamoto I. Mammalian X-Chromosome Inactivation: An Epigenetics Paradigm. Cold Spring Harbor Symposia on Quantitative Biology. 2004 Jan; 69(0):89-102. http://symposium.cshlp.org/ cgi/doi/10.1101/sqb.2004.69.89, doi: 10.1101/sqb.2004.69.89.

Hinten M, Maclary E, Gayen S, Harris C, Kalantry S. Visualizing Long Noncoding RNAs on Chromatin. In: Feng Y, Zhang L, editors. Long Non-Coding RNAs, vol. 1402 New York, NY: Springer New York; 2016.p. 147-164. http://link.springer.com/10.1007/978-1-4939-3378-5_12, doi: 10.1007/978-1-4939-3378-5_12, series Title: Methods in Molecular Biology.

Ichihara S, Nagao K, Sakaguchi T, Obuse C, Sado T. SmcHD1 underlies the formation of H3K9me3 blocks on the inactive X chromosome in mice. bioRxiv. 2021 Aug; http://biorxiv.org/lookup/doi/10.1101/2021.08.23.457321, doi: 10.1101/2021.08.23.457321.

Inoue A, Jiang L, Lu F, Zhang Y. Genomic imprinting of Xist by maternal H3K27me3. Genes \& Development. 2017 Oct; 31(19):1927-1932. http://genesdev.cshlp.org/lookup/doi/10.1101/gad.304113.117, doi: 10.1101/gad.304113.117.

Jansz N, Keniry A, Trussart M, Bildsoe H, Beck T, Tonks ID, Mould AW, Hickey P, Breslin K, Iminitoff M, Ritchie ME, McGlinn E, Kay GF, Murphy JM, Blewitt ME. Smchd1 regulates long-range chromatin interactions on the inactive X chromosome and at Hox clusters. Nature Structural \& Molecular Biology. 2018 Sep; 25(9):766-777. http://www.nature.com/articles/s41594-018-0111-z, doi: 10.1038/s41594-018-0111-z.

Jansz N, Nesterova T, Keniry A, Iminitoff M, Hickey PF, Pintacuda G, Masui O, Kobelke S, Geoghegan N, Breslin KA, Willson TA, Rogers K, Kay GF, Fox AH, Koseki H, Brockdorff N, Murphy JM, Blewitt ME. Smchd1 Targeting to the Inactive X Is Dependent on the Xist-HnrnpK-PRC1 Pathway. Cell Reports. 2018 Nov; 25(7):1912-1923.e9. https://linkinghub.elsevier.com/retrieve/pii/S2211124718316334, doi: 10.1016/j.celrep.2018.10.044.

Kariyawasam H, Su S, Voogd O, Ritchie ME, Law CW. Dashboard-style interactive plots for RNA-seq analysis are R Markdown ready with Glimma 2.0. bioRxiv. 2021 Aug; http:/ / biorxiv.org/lookup/doi/10.1101/2021.07.30.454464, doi: 10.1101/2021.07.30.454464.

Keniry A, Gearing LJ, Jansz N, Liu J, Holik AZ, Hickey PF, Kinkel SA, Moore DL, Breslin K, Chen K, Liu R, Phillips C, Pakusch M, Biben C, Sheridan JM, Kile BT, Carmichael C, Ritchie ME, Hilton DJ, Blewitt ME. Setdb1-mediated H3K9 methylation is enriched on the inactive $X$ and plays a role in its epigenetic silencing. Epigenetics \& Chromatin. 2016 Dec; 9(1):16. https://epigeneticsandchromatin.biomedcentral.com/articles/10.1186/ s13072-016-0064-6, doi: 10.1186/s13072-016-0064-6.

Kim D, Langmead B, Salzberg SL. HISAT: a fast spliced aligner with low memory requirements. Nature Methods. 2015 Apr; 12(4):357-360. http://www.nature.com/articles/nmeth.3317, doi: 10.1038/nmeth.3317.

Krueger F, Andrews SR. SNPsplit: Allele-specific splitting of alignments between genomes with known SNP genotypes. F1000Research. 2016 Jun; 5:1479. https://f1000research.com/articles/5-1479/v1, doi: 10.12688/f1000research.9037.1.

Lemmers RJLF, Tawil R, Petek LM, Balog J, Block GJ, Santen GWE, Amell AM, van der Vliet PJ, Almomani R, Straasheijm KR, Krom YD, Klooster R, Sun Y, den Dunnen JT, Helmer Q, Donlin-Smith CM, Padberg GW, van Engelen BGM, de Greef JC, Aartsma-Rus AM, et al. Digenic inheritance of an SMCHD1 mutation and an FSHD-permissive D4Z4 allele causes facioscapulohumeral muscular dystrophy type 2. Nature Genetics. 2012 Dec; 44(12):1370-1374. http://www.nature.com/articles/ng.2454, doi: 10.1038/ng.2454.

Levesque MJ, Ginart P, Wei Y, Raj A. Visualizing SNVs to quantify allele-specific expression in single cells. Nature Methods. 2013 Sep; 10(9):865-867. http://www.nature.com/articles/nmeth.2589, doi: 10.1038/nmeth.2589.

Liao Y, Smyth GK, Shi W. featureCounts: an efficient general purpose program for assigning sequence reads to genomic features. Bioinformatics. 2014 Apr; 30(7):923-930. https://academic.oup.com/bioinformatics/ article-lookup/doi/10.1093/bioinformatics/btt656, doi: 10.1093/bioinformatics/btt656.

Liao Y, Smyth GK, Shi W. The R package Rsubread is easier, faster, cheaper and better for alignment and quantification of RNA sequencing reads. Nucleic Acids Research. 2019 May; 47(8):e47-e47. https: / academic oup.com/nar/article/47/8/e47/5345150, doi: 10.1093/nar/gkz114.

Lyon MF. Sex chromatin and gene action in the mammalian X-chromosome. American Journal of Human Genetics. 1962 Jun; 14:135-148.

Lyon MF. Gene Action in the X-chromosome of the Mouse (Mus musculus L.). Nature. 1961 Apr; 190(4773):372-373. http://www.nature.com/articles/190372a0, doi: 10.1038/190372a0. 
Lyon MF. Attempts to test the inactive-X theory of dosage compensation in mammals. Genetical Research. 1963 Feb; 4(1):93-103. https://www.cambridge.org/core/product/identifier/S0016672300003451/type/journal_article, doi: $10.1017 /$ S0016672300003451.

McCarthy DJ, Chen Y, Smyth GK. Differential expression analysis of multifactor RNA-Seq experiments with respect to biological variation. Nucleic Acids Research. 2012 May; 40(10):4288-4297. https://academic.oup. com/nar/article/40/10/4288/2411520, doi: 10.1093/nar/gks042.

McGraw S, Oakes CC, Martel J, Cirio MC, de Zeeuw P, Mak W, Plass C, Bartolomei MS, Chaillet JR, Trasler JM. Loss of DNMT1o Disrupts Imprinted X Chromosome Inactivation and Accentuates Placental Defects in Females. PLoS Genetics. 2013 Nov; 9(11):e1003873. https://dx.plos.org/10.1371/journal. pgen.1003873, doi: 10.1371/journal.pgen.1003873.

Mei H, Kozuka C, Hayashi R, Kumon M, Koseki H, Inoue A. H2AK119ub1 guides maternal inheritance and zygotic deposition of H3K27me3 in mouse embryos. Nature Genetics. 2021 Apr; http:/ / www.nature.com/articles/ s41588-021-00820-3, doi: 10.1038/s41588-021-00820-3.

Mould AW, Pang Z, Pakusch M, Tonks ID, Stark M, Carrie D, Mukhopadhyay P, Seidel A, Ellis JJ, Deakin J, Wakefield MJ, Krause L, Blewitt ME, Kay GF. Smchd1 regulates a subset of autosomal genes subject to monoallelic expression in addition to being critical for X inactivation. Epigenetics \& Chromatin. 2013 Dec; 6(1):19. https: //epigeneticsandchromatin.biomedcentral.com/articles/10.1186/1756-8935-6-19, doi: 10.1186/1756-8935-6-19.

Okamoto I, Heard E. The dynamics of imprinted X inactivation during preimplantation development in mice. Cytogenetic and Genome Research. 2006; 113(1-4):318-324. https://www.karger.com/Article/FullText/90848, doi: 10.1159/000090848.

Okamoto I, Patrat C, Thépot D, Peynot N, Fauque P, Daniel N, Diabangouaya P, Wolf JP, Renard JP, Duranthon V, Heard E. Eutherian mammals use diverse strategies to initiate X-chromosome inactivation during development. Nature. 2011 Apr; 472(7343):370-374. http://www.nature.com/articles/nature09872, doi: 10.1038/nature09872.

Patrat C, Okamoto I, Diabangouaya P, Vialon V, Le Baccon P, Chow J, Heard E. Dynamic changes in paternal $X$-chromosome activity during imprinted X-chromosome inactivation in mice. Proceedings of the National Academy of Sciences. 2009 Mar; 106(13):5198-5203. http://www.pnas.org/cgi/doi/10.1073/pnas.0810683106, doi: 10.1073/pnas.0810683106.

Prissette M. Methylation profiles of DXPas34 during the onset of X-inactivation. Human Molecular Genetics. 2001 Jan; 10(1):31-38. https://academic.oup.com/hmg/article-lookup/doi/10.1093/hmg/10.1.31, doi: 10.1093/hmg/10.1.31.

R Core Team. R: A Language and Environment for Statistical Computing. R Foundation for Statistical Computing, Vienna, Austria; 2019, https://www.R-project.org/.

Raas MWD, Zijlmans DW, Vermeulen M, Marks H. There is another: H3K27me3-mediated genomic imprinting. Trends in Genetics. 2021 Jul; p. S0168952521001876. https://linkinghub.elsevier.com/retrieve/ pii/S0168952521001876, doi: 10.1016/j.tig.2021.06.017.

Reik W, Lewis A. Co-evolution of X-chromosome inactivation and imprinting in mammals. Nature Reviews Genetics. 2005 May; 6(5):403-410. http:/ www.nature.com/articles/nrg1602, doi: 10.1038/nrg1602.

Robinson MD, McCarthy DJ, Smyth GK. edgeR: a Bioconductor package for differential expression analysis of digital gene expression data. Bioinformatics. 2010 Jan; 26(1):139-140. https:/ academic.oup.com/bioinformatics/ article-lookup/doi/10.1093/bioinformatics/btp616, doi: 10.1093/bioinformatics/btp616.

Robinson MD, Oshlack A. A scaling normalization method for differential expression analysis of RNA-seq data. Genome Biology. 2010; 11(3):R25. http://genomebiology.biomedcentral.com/articles/10.1186/gb-2010-11-3-r25, doi: 10.1186/gb-2010-11-3-r25.

Schroeder DI, Jayashankar K, Douglas KC, Thirkill TL, York D, Dickinson PJ, Williams LE, Samollow PB, Ross PJ, Bannasch DL, Douglas GC, LaSalle JM. Early Developmental and Evolutionary Origins of Gene Body DNA Methylation Patterns in Mammalian Placentas. PLOS Genetics. 2015 Aug; 11(8):e1005442. https: //dx.plos.org/10.1371/journal.pgen.1005442, doi: 10.1371/journal.pgen.1005442.

Su S, Law CW, Ah-Cann C, Asselin-Labat ML, Blewitt ME, Ritchie ME. Glimma: interactive graphics for gene expression analysis. Bioinformatics. 2017 Jul; 33(13):2050-2052. https://academic.oup.com/bioinformatics/ article/33/13/2050/2997287, doi: 10.1093/bioinformatics/btx094. 
Tada T, Obata Y, Tada M, Goto Y, Nakatsuji N, Tan S, Kono T, Takagi N. Imprint switching for non-random X-chromosome inactivation during mouse oocyte growth. Development. 2000 Jul; 127(14):3101-3105. https: //journals.biologists.com/dev/article/127/14/3101/40816/Imprint-switching-for-non-random-X-chromosome, doi: 10.1242/dev.127.14.3101.

Wagner KU, Wall RJ, St-Onge L, Gruss P, Wynshaw-Boris A, Garrett L, Li M, Furth PA, Hennighausen L. Cremediated gene deletion in the mammary gland. Nucleic Acids Research. 1997 Nov; 25(21):4323-4330. https://academic.oup.com/nar/article-lookup/doi/10.1093/nar/25.21.4323, doi: 10.1093/nar/25.21.4323.

Wang CY, Colognori D, Sunwoo H, Wang D, Lee JT. PRC1 collaborates with SMCHD1 to fold the X-chromosome and spread Xist RNA between chromosome compartments. Nature Communications. 2019 Dec; 10(1):2950. http://www.nature.com/articles/s41467-019-10755-3, doi: 10.1038/s41467-019-10755-3.

Wang CY, Jégu T, Chu HP, Oh HJ, Lee JT. SMCHD1 Merges Chromosome Compartments and Assists Formation of Super-Structures on the Inactive X. Cell. 2018 Jul; 174(2):406-421.e25. https://linkinghub.elsevier.com/retrieve/ pii/S0092867418305841, doi: 10.1016/j.cell.2018.05.007.

Wanigasuriya I, Gouil Q, Kinkel SA, Tapia del Fierro A, Beck T, Roper EA, Breslin K, Stringer J, Hutt K, Lee HJ, Keniry A, Ritchie ME, Blewitt ME. Smchd1 is a maternal effect gene required for genomic imprinting. eLife. 2020 Nov; 9:e55529. https://elifesciences.org/articles/55529, doi: 10.7554/eLife.55529.

Wutz A, Jaenisch R. A Shift from Reversible to Irreversible X Inactivation Is Triggered during ES Cell Differentiation. Molecular Cell. 2000 Apr; 5(4):695-705. https://linkinghub.elsevier.com/retrieve/pii/S1097276500802488, doi: 10.1016/S1097-2765(00)80248-8.

Xue Y, Zhong Z, Harris CJ, Gallego-Bartolomé J, Wang M, Picard C, Cao X, Hua S, Kwok I, Feng S, Jami-Alahmadi Y, Sha J, Gardiner J, Wohlschlegel J, Jacobsen SE. Arabidopsis MORC proteins function in the efficient establishment of RNA directed DNA methylation. Nature Communications. 2021 Dec; 12(1):4292. http:/ /www. nature.com/ articles/s41467-021-24553-3, doi: 10.1038/s41467-021-24553-3.

Zeng TB, Pierce N, Szabó PE. H3K9 methyltransferase EHMT2/G9a controls ERVK-driven non-canonical imprinted genes. bioRxiv. 2021 Mar; http://biorxiv.org/lookup/doi/10.1101/2021.03.29.437617, doi: 10.1101/2021.03.29.437617. 
bioRxiv preprint doi: https://doi.org/10.1101/2021.10.21.465360; this version posted October 21, 2021. The copyright holder for this preprint (which was not certified by peer review) is the author/funder, who has granted bioRxiv a license to display the preprint in perpetuity. It is made available under aCC-BY-NC-ND 4.0 International license.

\section{Appendix 1}

\section{Supplementary files}

1. tables of differential expression results: male and female E2.75 mat $\Delta$ vs wt embryos (total and allelic), female E14.5 mat $\Delta$ vs wt placentae (allelic), female E14.5 het vs wt placentae (allelic).

2. tables of differential methylation results: female E2.75 mat $\Delta \mathrm{vs}$ wt embryos in $10 \mathrm{~kb}$ windows, at promoters and at CGIs. 
bioRxiv preprint doi: https://doi.org/10.1101/2021.10.21.465360; this version posted October 21, 2021. The copyright holder for this preprint (which was not certified by peer review) is the author/funder, who has granted bioRxiv a license to display the preprint in perpetuity. It is made available under aCC-BY-NC-ND 4.0 International license.

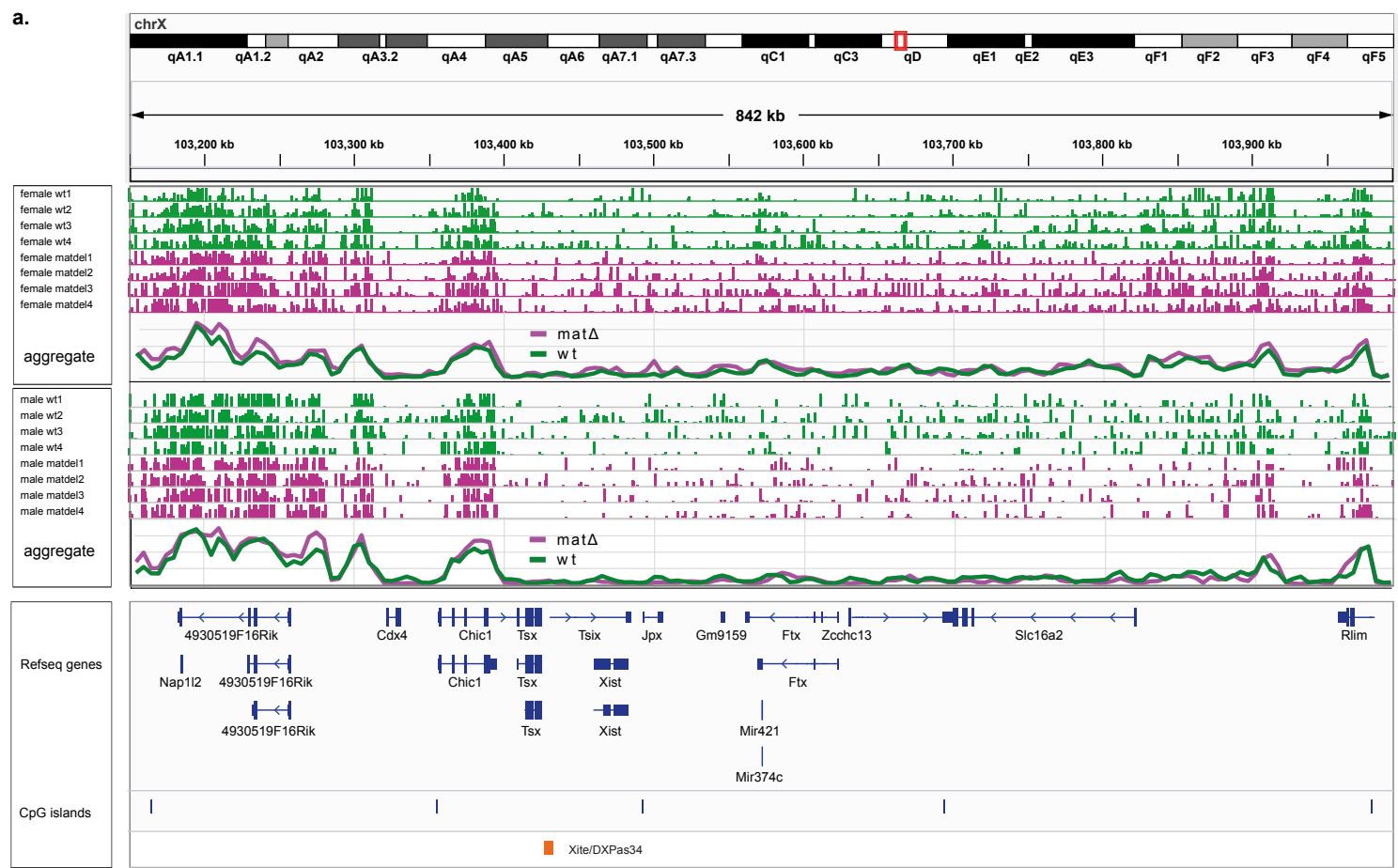

Figure 1-Figure supplement 1. DNA methylation at the $X$ inactivation center in female and male E2.75 wt embryos and Smchd $1^{\text {mat } \Delta}$ embryos. Histogram tracks show methylation in single embryos at individual CpG sites (0-100\%, 4 wild-type and 4 mat $\Delta$ embryos shown for each sex). Note that coverage in single-embryo whole-genome bisulfite sequencing is sparse, only $0-2 X$. The aggregate line plots show the average methylation per genotype across $10 \mathrm{~kb}$ windows (sliding by $5 \mathrm{~kb}, 0-100 \%$ ). Females: $\mathrm{n}=6 \mathrm{wt}$ and 4 mat $\Delta$; males: $\mathrm{n}=5 \mathrm{wt}$ and 8 mat $\Delta$.
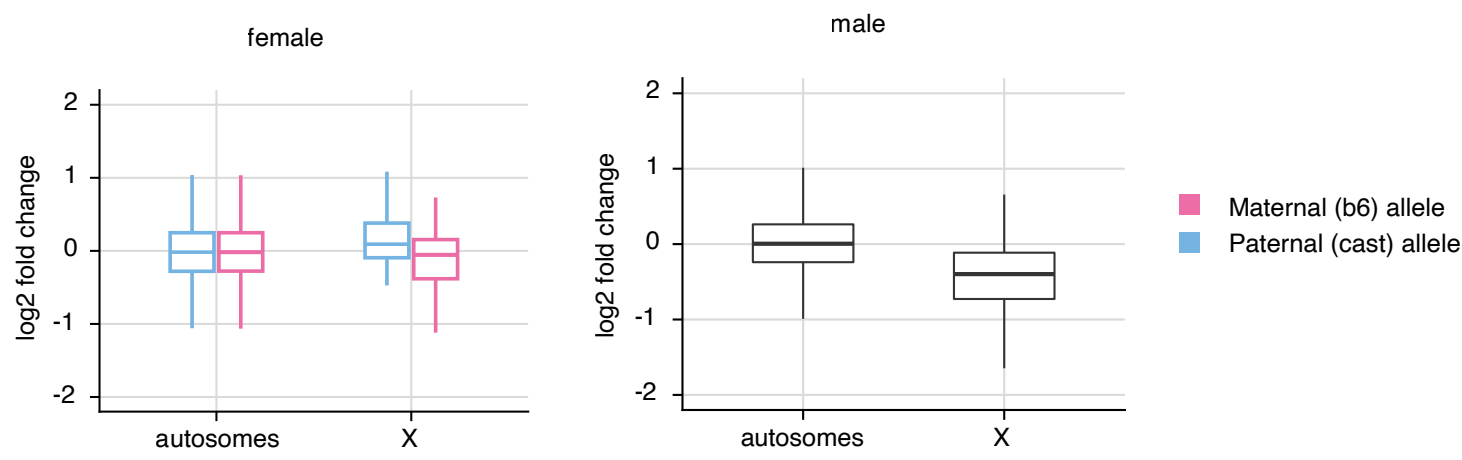

Figure 2-Figure supplement 1. Distribution of $S m c h d 1^{m a t} \Delta$ vs wt gene expression $\log _{2}$ fold changes on autosomes and the $\mathrm{X}$ chromosome for male and female E2.75 embryos, retaining only mat $\Delta$ embryos with loss of Xist imprinting. 
bioRxiv preprint doi: https://doi.org/10.1101/2021.10.21.465360; this version posted October 21, 2021. The copyright holder for this preprint (which was not certified by peer review) is the author/funder, who has granted bioRxiv a license to display the preprint in perpetuity. It is made available under aCC-BY-NC-ND 4.0 International license.
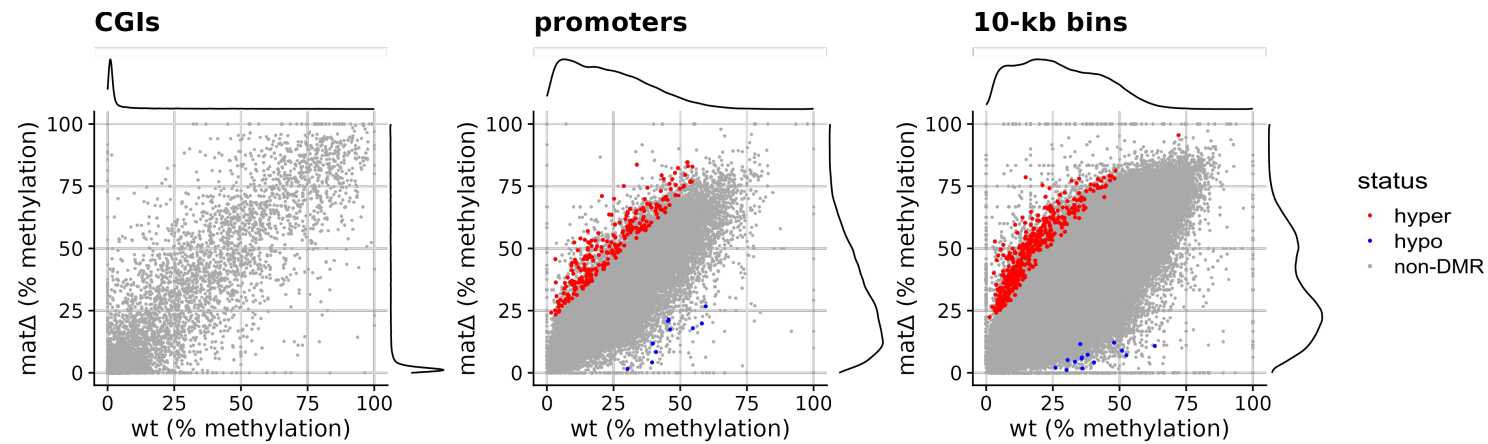

Figure 2-Figure supplement 2. Whole-genome differential methylation analysis between female Smchd $1^{\text {mat } \Delta}$ and wild-type E2.75 embryos. For CpG islands (CGls, 13k regions), promoters ( $-4 \mathrm{~kb}$ to $+1 \mathrm{~kb}$ regions, $52 \mathrm{k}$ regions) and $10-\mathrm{kb}$ windows (sliding by $5 \mathrm{~kb}, 500 \mathrm{k}$ regions), the average methylation level in wild types is plotted against the average methylation in $S m c h d 1^{\text {mat } \Delta}$ embryos. Significant Differentially Methylated Regions (DMRs, FDR $<5 \%$ and absolute difference in methylation $>20 \%$ ) are coloured in red (hypermethylation) or blue (hypomethylation). Females: $n=6$ wt and 4 mat $\Delta$. 